FOLIA

HORTICULTURAE

Ann. 21/1, 2009, 3-16

DOI: $10.2478 /$ fhort-2013-012

\title{
The effect of nitrogen fertilizer form and foliar application on the concentrations of twenty-five elements in carrot
}

\author{
Sylwester Smoleń, Włodzimierz Sady \\ Department of Soil Cultivation and Fertilization of Horticultural Plants \\ Faculty of Horticulture, University of Agriculture in Krakow \\ 29 Listopada 54, 31-425 Kraków, Poland \\ e-mail: ssmolen@bratek.ogr.ar.krakow.pl
}

Key words: fertilization, foliar nutrition, heavy metals, macroelements, microelements, trace elements

\begin{abstract}
Among all elements taken into consideration in this research (Al, As, B, Ba, Be, Bi, $\mathrm{Ca}, \mathrm{Co}, \mathrm{Cr}, \mathrm{Fe}, \mathrm{Ga}$, In, K, Li, Mg, Mn, Mo, Na, Ni, Pb, Sb, Se, Sr, Ti and V), only the concentration of $\mathrm{Na}$ in the 'Kazan $\mathrm{F}_{1}$ ' carrot was affected by the interaction of foliar application and nitrogen fertilization. In the case of plants fertilized by $\mathrm{Ca}\left(\mathrm{NO}_{3}\right)_{2}$, foliar application significantly raised $\mathrm{Na}$ concentration in storage roots. Compared to the control, all applied nitrogen fertilizers (results analysed independently from the foliar application factor) increased concentrations of $\mathrm{Mg}$ and $\mathrm{Se}$ in carrot. Fertilization with $\left(\mathrm{NH}_{4}\right)_{2} \mathrm{SO}_{4}$ resulted in a decrease of $\mathrm{Ba}$ and $\mathrm{Mo}$ concentrations and an increase of $\mathrm{Mn}$ concentration, while fertilization with $\mathrm{Ca}\left(\mathrm{NO}_{3}\right)_{2}$ raised the contents of $\mathrm{Sr}$ and $\mathrm{Be}$ in carrot. Foliar application (analysed independently from nitrogen fertilization) considerably increased $\mathrm{Bi}$ and $\mathrm{Be}$ concentrations, yet it did not affect the contents of other elements in storage roots.
\end{abstract}




\section{INTRODUCTION}

Nitrogen fertilizers most frequently contain nitrogen in its oxygenated form $\left(\mathrm{N}-\mathrm{NO}_{3}\right)$ present in physiologically alkaline fertilizers, or in its reduced form $\left(\mathrm{N}-\mathrm{NH}_{4}\right.$ and $\left.\mathrm{N}-\mathrm{NH}_{2}\right)$, present in physiologically acid fertilizers. Apart from nitrogen, nitrogen fertilizers can contain other nutrients elements such as $\mathrm{Ca}, \mathrm{K}$, $\mathrm{Mg}$ and $\mathrm{Na}$ (a group of physiologically alkaline fertilizers: calcium nitrate, potassium nitrate, magnesium nitrate and sodium nitrate) or $\mathrm{S}$ and $\mathrm{Cl}$ (a group of physiologically acid fertilizers: ammonium sulfate and ammonium chloride). Depending on the content of reduced or oxygenated forms of nitrogen, or accompanying nutrients, fertilizers can variously affect chemical properties of soil (Czekała and Jakubus 2006, Diatta and Grzebisz 2006) and invoke varied physiological effects in plants, e.g. on the level of nitrate accumulation (Rożek 2000, Smoleń et al. 2006) or heavy metal accumulation (Gębski 1998, Maier et al. 2002, Sady and Smoleń 2004, Rodríguez-Ortíz et al. 2006, Hassan et al. 2005, 2008).

In comparison with oxygenated forms of nitrogen, fertilization with reduced forms of nitrogen normally causes an increased level of heavy metal accumulation in plants. This was also showed in the works of many authors (Gębski 1998, Sady and Smolen 2004). The majority of studies examining the effect of a particular form of nitrogen fertilizer on the mineral content of plants are dedicated to assessing their interaction on the accumulation level of individual heavy metals in plants (Gębski and Mercik 1997, Rodríguez-Ortíz et al. 2006, Hassan et al. 2008). Few authors took a comprehensive approach to assess the effect of various forms of nitrogen on the content of macro- and micronutrients and heavy metals in plants (Jurkowska et al. 1981, Jurkowska and Rogóż 1981, Maier et al. 2002, Smoleń and Sady 2008). There is no work in the literature that would comprehensively evaluate the effect of nitrogen forms combined with foliar application on the content of macro- and micronutrients, heavy metals and trace elements in plants.

This research aimed at assessing $\mathrm{Ca}\left(\mathrm{NO}_{3}\right)_{2}, \mathrm{NH}_{4} \mathrm{NO}_{3}, \quad\left(\mathrm{NH}_{4}\right)_{2} \mathrm{SO}_{4}$ and $\mathrm{CO}\left(\mathrm{NH}_{2}\right)_{2}$ and the foliar application effect on the concentration of twenty five elements (Al, As, B, Ba, Be, Bi, Ca, Co, Cr, Fe, Ga, In, K, Li, Mg, Mn, Mo, Na, $\mathrm{Ni}, \mathrm{Pb}, \mathrm{Sb}, \mathrm{Se}, \mathrm{Sr}, \mathrm{Ti}$ and $\mathrm{V}$ ) in carrot storage roots.

\section{MATERIAL AND METHODS}

In $2004-2005$ the 'Kazan $\mathrm{F}_{1}$ ' carrot was cultivated in latticed containers $60 \times 40 \times$ $20 \mathrm{~cm}$, placed in an open field under shade-providing fabric. The containers were filled with a medium silt loam (35\% sand, $28 \%$ silt and $37 \%$ clay) with the mean content of organic substance of $3.25 \%$. The $\mathrm{pH}_{\mathrm{H}_{2} \mathrm{O}}$ soil reaction was $7.29, \mathrm{pH}_{\mathrm{KCl}}$ 6.70 , while total salt concentration was on the level of $0.45 \mathrm{EC}$ in $\mathrm{mS} \mathrm{cm}^{-1}$. In both 
years of the study the soil (topsoil 0-30 cm), classified as alluvial soil, was obtained from the same field in the Mydlniki district of Krakow in Poland.

Seeds were sown on 20.04.2004 and on 27.04.2005. The content of assimilable nutrient forms during the vegetation period was maintained on the following levels: P $80 \mathrm{mg}, \mathrm{K} 120 \mathrm{mg}, \mathrm{Mg} 80 \mathrm{mg}$, and Ca $2000 \mathrm{mg} \mathrm{dm}^{-3}$ of soil by means of fertilization (based on the results of the soil chemical analysis) conducted on 8.04 and 5.07 in 2004 and on 25.04 and 1.07 in 2005. Nutrients were applied to the soil as fertilizers: $\mathrm{KH}_{2} \mathrm{PO}_{4}, \mathrm{~K}_{2} \mathrm{SO}_{4}$ (as soluble fertilizer produced by Yara), $\mathrm{MgSO}_{4} \cdot 7 \mathrm{H}_{2} \mathrm{O}$ with microelements (comprising: $0.35 \% \mathrm{Mn}, 0.3 \% \mathrm{Cu}, 0.2 \% \mathrm{Zn}, 0.05 \% \mathrm{~B}$ and $0.01 \%$ Mo, produced by Intermag) and $\mathrm{CaCO}_{3}$ (produced by EKO-WAP). The fertilizer $\mathrm{MgSO}_{4} \cdot 7 \mathrm{H}_{2} \mathrm{O}$ with microelements supplied the soil with about $2.5 \mathrm{mg} \mathrm{Cu}$ and $1.66 \mathrm{mg} \mathrm{Zn} \mathrm{per} \mathrm{dm}^{-3}$. The soil was fertilized with nitrogen three times during the vegetation period (i.e. on 20.04, 5.07 and 23.08 in 2004, and on 25.04, 1.07 and 22.08 in 2005), based on the results of the soil chemical analysis to supplement the $\mathrm{N}$-mineral content to the level of $100 \mathrm{mg} \mathrm{dm}^{-3}$ of soil.

The research comprised two sub-blocks with plant foliar application and without foliar nutrition. In the sub-block with foliar application the plants were sprayed three times (on 30.06, 6.08 and 24.08 in 2004 and 28.06, 1.08 and 23.08 in 2005 ) with $2 \%$ of urea solution, $1 \%$ of Supervit $\mathrm{R}$ fertilizer solution and again with $2 \%$ urea solution. Supervit $\mathrm{R}$ brand fertilizer contains (percentage by weight): $3.5 \%$ $\mathrm{N}\left(1.0 \% \mathrm{~N}-\mathrm{NO}_{3}, 2.5 \% \mathrm{~N}-\mathrm{NH}_{2}\right), 3.4 \% \mathrm{~K}_{2} \mathrm{O}, 0.6 \% \mathrm{MgO}, 0.04 \% \mathrm{Mn}$ and $0.02 \% \mathrm{~B}$, $\mathrm{Cu}$, Ti and $\mathrm{Zn}-$ each, $0.012 \% \mathrm{Fe}$ and $0.001 \% \mathrm{Mo}$. The following combinations with soil fertilized with nitrogen were distinguished within the sub-blocks: 1 - control (unfertilized with nitrogen), $2-\mathrm{Ca}\left(\mathrm{NO}_{3}\right)_{2}, 3-\mathrm{NH}_{4} \mathrm{NO}_{3}, 4-\left(\mathrm{NH}_{4}\right)_{2} \mathrm{SO}_{4}$ and $5-\mathrm{CO}\left(\mathrm{NH}_{2}\right)_{2}$. Nitrogen was applied to the soil as fertilizer produced by: $\mathrm{Ca}\left(\mathrm{NO}_{3}\right)_{2}$ (as soluble fertilizer) - Yara, $\mathrm{NH}_{4} \mathrm{NO}_{3}, \mathrm{CO}\left(\mathrm{NH}_{2}\right)_{2}-$ Zakłady Azotowe, Puławy, $\left(\mathrm{NH}_{4}\right)_{2} \mathrm{SO}_{4}-$ Zakłady Azotowe, Tarnów.

Carrot was harvested and its yield was assessed on 15.09.2004 and 27.09.2005. At the same time the soil was sampled for analyses from the sub-block where foliar application was not applied. The soil reaction $\mathrm{pH}$ was assessed by potentiometer (Nowosielski 1988) and organic matter with the Tiurin method modified by Oleksynowa (Komornicki et al. 1991).

Every year, disintegrated plant material (carrot storage roots) was dried at $70^{\circ} \mathrm{C}$, and subsequently ground in a laboratory grinder and stored in tightly packed plastic bags. After the end of a two-year research cycle, the stored plant material (collected in the years $2004-2005$ ) was mineralized in $65 \%$ super pure $\mathrm{HNO}_{3}$ (Merck no. 100443.2500) in a CEM MARS-5 Xpress microwave oven (Pasławski and Migaszewski 2006).

Soil samples collected after the end of cultivation were dried in the open air, ground, sieved with $1 \mathrm{~mm}$ mesh sieve and stored in tightly packed plastic bags. After the end of the experiment cycle, soil samples were extracted with 
$0.01 \mathrm{M} \mathrm{CaCl}_{2}$ (Houba et al. 1997). The content of twenty-five elements (Al, As, B, $\mathrm{Ba}, \mathrm{Be}, \mathrm{Bi}, \mathrm{Ca}, \mathrm{Co}, \mathrm{Cr}, \mathrm{Fe}, \mathrm{Ga}$, In, K, Li, Mg, Mn, Mo, Na, Ni, Pb, Sb, Se, Sr, Ti and $\mathrm{V}$ ) in mineralized plant material and soil extracts (except of $\mathrm{Ca}$ in soil extracts) was determined using the ICP-OES method (Houba et al. 1997, Pasławski and Migaszewski 2006) with the use of a Prodigy Teledyne Leeman Labs USA spectrometer. The ICP-OES instrument was calibrated using Merck's ICP multielement standard no. VI and no. XVI and Inorganic Ventures ICP single element standards of $\mathrm{K}, \mathrm{Mg}, \mathrm{Ca}$ and $\mathrm{Na}$.

Statistical calculations of the obtained results were performed with the use of the ANOVA module of Statistica 7.1 PL for $p<0.05$. Significance of variations was assessed with the help of variance analysis. In case of significance of changes, homogenous groups were determined on the basis of the Duncan test. A more detailed description of the experiment was presented in the earlier work (Smolen and Sady 2007 a).

\section{RESULTS}

As shown by statistical analysis, among all examined elements (Al, As, B, Ba, Be, $\mathrm{Bi}, \mathrm{Ca}, \mathrm{Co}, \mathrm{Cr}, \mathrm{Fe}, \mathrm{Ga}$, In, K, Li, Mg, Mn, Mo, Na, Ni, Pb, Sb, Se, Sr, Ti and V) there was a significant effect of the interaction between foliar application and nitrogen fertilization only in the case of $\mathrm{Na}$ content in carrot storage roots (Tables 1 and 2). The roots of plants fertilized with $\mathrm{Ca}\left(\mathrm{NO}_{3}\right)_{2}$ and with foliar application contained the highest amounts of $\mathrm{Na}$. It shall be noted that they contained apparently higher amounts of $\mathrm{Na}$ than the plants fertilized with $\mathrm{Ca}\left(\mathrm{NO}_{3}\right)_{2}$ without foliar application.

The form of nitrogen fertilizer (analysed irrespective of foliar application) significantly affected the concentrations of $\mathrm{Mg}, \mathrm{Ba}, \mathrm{Mn}, \mathrm{Sr}$ (Table 1) as well as $\mathrm{Be}$, Mo and Se (Table 2) in carrot storage roots. When compared to the control, all forms of applied nitrogen fertilizers caused a distinctive increase in the $\mathrm{Mg}$ content in carrot. A similar tendency was revealed in case of Se; however, the storage roots of plants fertilized with $\mathrm{Ca}\left(\mathrm{NO}_{3}\right)_{2}$ and $\mathrm{NH}_{4} \mathrm{NO}_{3}$ were characterized by comparable concentrations of this element to the control plants. When compared with other combinations, fertilization with $\left(\mathrm{NH}_{4}\right)_{2} \mathrm{SO}_{4}$ resulted in a significant decrease of $\mathrm{Ba}$ and Mo concentration, and an increase in Mn concentration, while fertilization with $\mathrm{Ca}\left(\mathrm{NO}_{3}\right)_{2}$ evidently raised $\mathrm{Sr}$ and $\mathrm{Be}$ in carrot.

Foliar application (analysed irrespective of nitrogen fertilization) considerably increased the concentration of $\mathrm{Bi}$ and $\mathrm{Be}$ in carrot, with no effect on the content of other elements tested (Tables 1 and 2). 


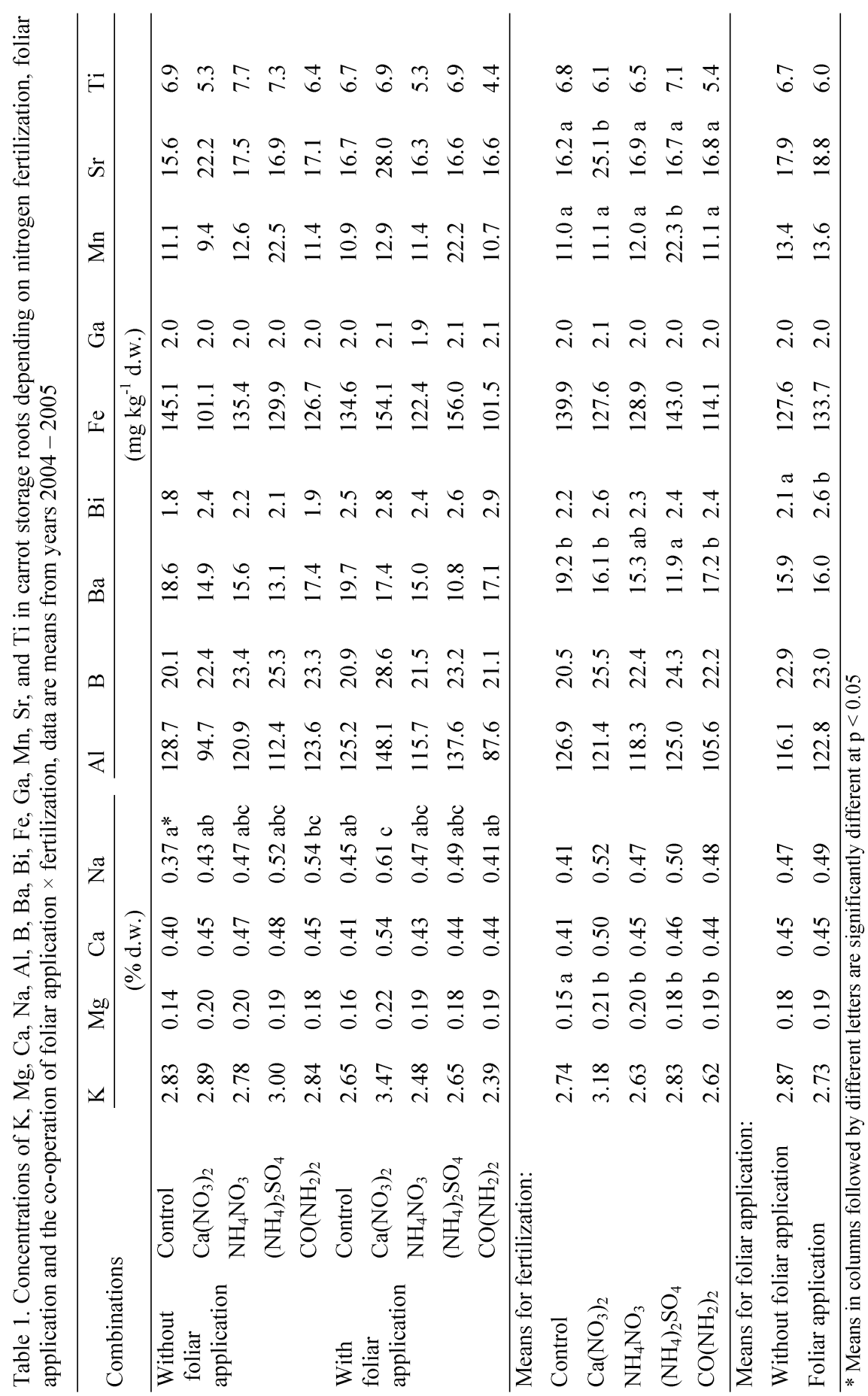




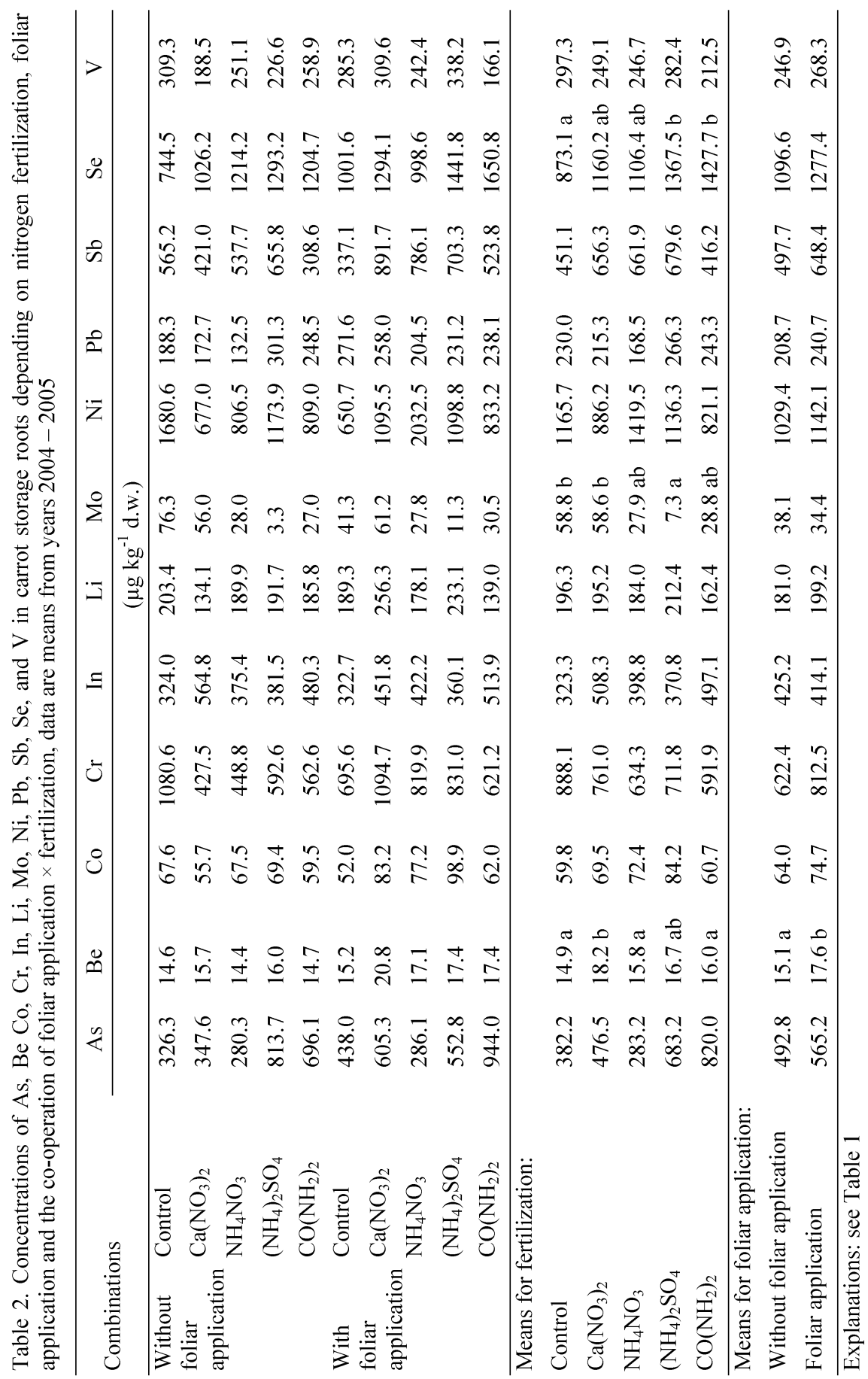




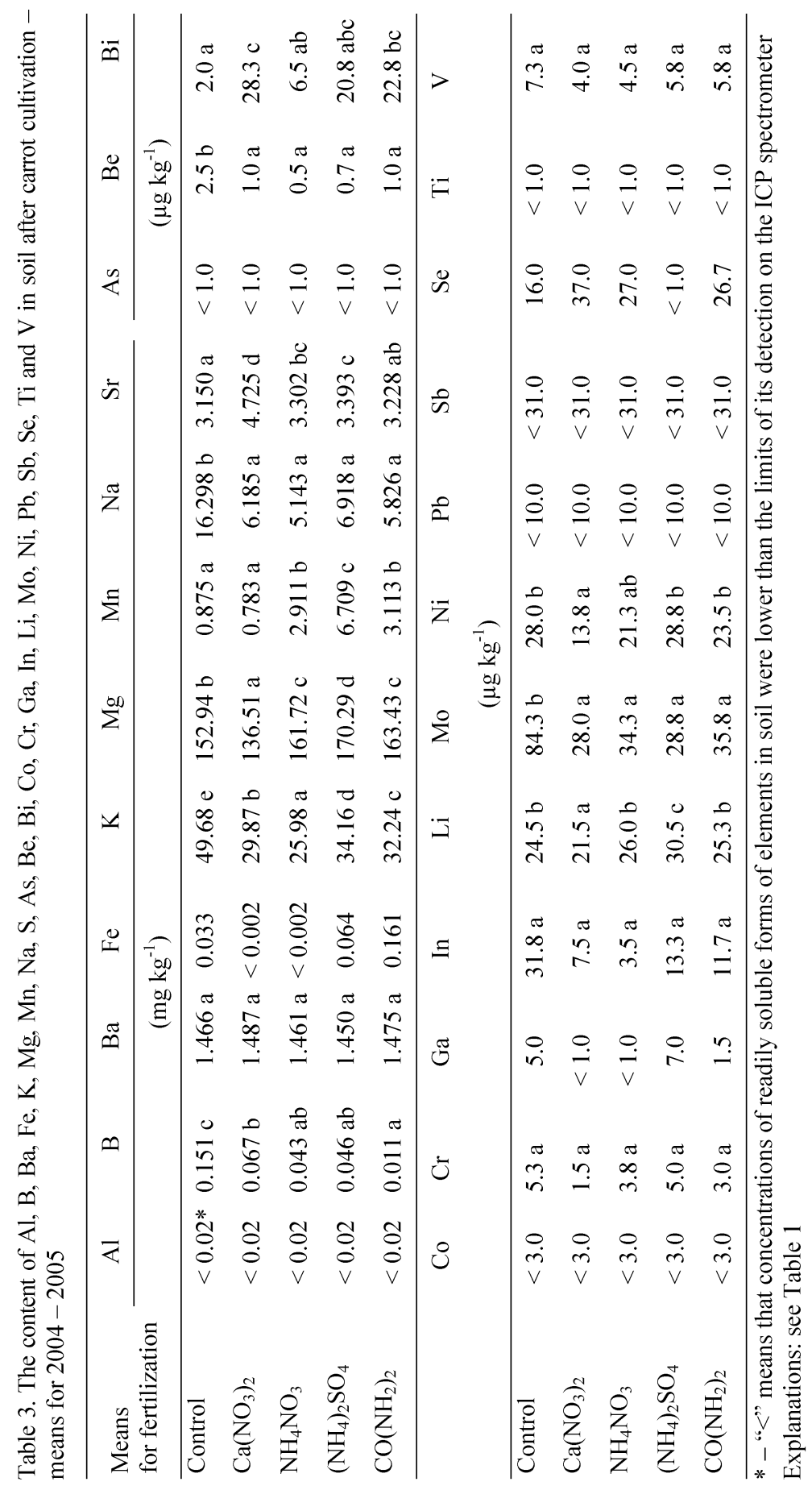


The results of the soil chemical analysis after carrot cultivation revealed a significant effect of applied fertilization on the concentrations of readily soluble forms (in $0.01 \mathrm{M} \mathrm{CaCl}_{2}$ ) of $\mathrm{B}, \mathrm{K}, \mathrm{Mg}, \mathrm{Mn}, \mathrm{Na}, \mathrm{Sr}, \mathrm{Be}, \mathrm{Bi}, \mathrm{Li}$, Mo and $\mathrm{Ni}$, without any influence on the concentrations of $\mathrm{Ba}, \mathrm{Cr}$, In and $\mathrm{V}$ (Table 3). In comparison with the control, all applied nitrogen fertilizers caused a decrease in the level of $\mathrm{B}$, $\mathrm{K}, \mathrm{Na}, \mathrm{Be}$ and $\mathrm{Mo}$ in soil. The lowest level of $\mathrm{K}$ was assessed in the soil fertilized with $\mathrm{NH}_{4} \mathrm{NO}_{3}$. In case of $\mathrm{B}$, its content in the soil fertilized with $\mathrm{CO}\left(\mathrm{NH}_{2}\right)_{2}$ was 13.5 times lower than in the control. The lowest concentration of $\mathrm{Mg}$ and $\mathrm{Ni}$ and the highest of $\mathrm{Sr}$ and $\mathrm{Bi}$ was observed in the soil after $\mathrm{Ca}\left(\mathrm{NO}_{3}\right)_{2}$ fertilization. Soil fertilized with $\left(\mathrm{NH}_{4}\right)_{2} \mathrm{SO}_{4}$ revealed the highest amount of $\mathrm{Mg}, \mathrm{Mn}$ and $\mathrm{Li}$. It is worth noting that the concentration of $\mathrm{Mn}$ in the soil with this fertilizer was 7.6 times higher than in the control. It should also be emphasised that in the soil of all the experimental combinations, the contents of $\mathrm{Al}, \mathrm{As}, \mathrm{Co}, \mathrm{Pb}, \mathrm{Sb}$ and $\mathrm{Ti}$ were below that of the limits of their detection on the ICP spectrometer. Similar results were obtained after determination of $\mathrm{Fe}$ and $\mathrm{Ga}$ in soil fertilized with $\mathrm{Ca}\left(\mathrm{NO}_{3}\right)_{2}$ and $\mathrm{NH}_{4} \mathrm{NO}_{3}$, as well as in the case of $\mathrm{Se}$ in soil fertilized with $\left(\mathrm{NH}_{4}\right)_{2} \mathrm{SO}_{4}$. The results of earlier works (Smolen et al. 2006) showed that the soil from individual sites of the experiments was considerably varied with regards to the reaction and content of $\mathrm{Ca}$ determined in the extracts prepared with $0.03 \mathrm{M}$ acetic acid (Nowosielski 1988). The lowest reaction was assessed in the soil fertilized with $\left(\mathrm{NH}_{4}\right)_{2} \mathrm{SO}_{4} \mathrm{pH}$ 6.07, and the highest in the control and after fertilization with $\mathrm{Ca}\left(\mathrm{NO}_{3}\right)_{2} \mathrm{pH} 6.73$. The highest amount of $\mathrm{Ca}\left(2123.4 \mathrm{mg} \mathrm{dm}^{-3}\right.$ of soil) was noted in the site fertilized with $\mathrm{CO}\left(\mathrm{NH}_{2}\right)_{2}$, with the lowest content in the soil fertilized with $\mathrm{NH}_{4} \mathrm{NO}_{3}$, $\mathrm{Ca}\left(\mathrm{NO}_{3}\right)_{2}$ plus in the control $(1823.6,1834.9$ and $2030.6 \mathrm{mg} \mathrm{dm}$ of soil, respectively). The concentration of $\mathrm{Ca}$ in the soil with $\left(\mathrm{NH}_{4}\right)_{2} \mathrm{SO}_{4}$ fertilization was $2076.5 \mathrm{mg} \mathrm{dm}^{-3}$.

\section{DISCUSSION}

The physiological reaction of plants to the treatment of foliar application can be, among others, stimulation to take nutrients by the roots (Marschner 1995, Adamec 2002). However, the research conducted by Chwil and Szewczuk (2003) showed that double spraying of sugar beet with Rolvit B multi-component fertilizer caused a decline in $\mathrm{Cu}, \mathrm{Fe}$ and $\mathrm{Mn}$ in storage roots in comparison with the foliarly unfertilized control plants. The results of Smolen (2008) showed that the foliar application treatments had a significant effect on $\mathrm{Cd}$ concentration and any significant changes in the concentrations of $\mathrm{Fe}, \mathrm{Mn}, \mathrm{Pb}$ and $\mathrm{Zn}$ in the radish. In our research, taking into account twenty-five elements marked in carrot storage roots, as well as $\mathrm{Cd}, \mathrm{Cu}$ and $\mathrm{Zn}$ assessed earlier (Smolen and Sady 2007 a), we noted a significant influence of the interaction between foliar application and nitrogen 
fertilization only in case of the content of $\mathrm{Na}$ in plants with $\mathrm{Ca}\left(\mathrm{NO}_{3}\right)_{2}$ fertilization. A soil chemical analysis of studied elements was performed only on the foliarly unfertilized sub-block. The lack of assessment of Na contents, as well as other elements, in the soil from foliarly fertilized sub-block impedes a fully objective evaluation of the interaction.

It is worth emphasizing that apart from an elevated level of $\mathrm{Na}$, storage roots of plants with foliar application and fertilized with $\mathrm{Ca}\left(\mathrm{NO}_{3}\right)_{2}$ had evidently lower mass and higher nitrate content in comparison with plants fertilized similarly but without foliar application (Smoleń et al. 2006). The average correlation coefficient $\mathrm{R}^{2}$, calculated on the basis of results presented in this and previous works (Smoleń et al. 2006), between $\mathrm{NO}_{3}{ }^{-}$and $\mathrm{Na}$ in carrot storage roots was statistically significant for $\mathrm{p}<0.05$ and was 0.86 . Gorham (2007) reveals that by higher salinity of soil (caused mainly by elevated level of $\mathrm{Na}^{+}$and $\mathrm{Cl}^{-}$in soil) plants have a tendency to accumulate nitrate in vacuoles. Our research, however, did not reveal excessive salinity of soil (Smoleń et al. 2006), with mean total salt concentration in soil (EC) after carrot cultivation at $0.53 \mathrm{mS} \mathrm{cm}^{-1}$. Sodium is not an essential element for normal growth and development for plants of type $C_{3}$ (Gorham 2007), to which carrot belongs. However, our results show that despite a lower level of $\mathrm{Na}$ than $\mathrm{Ca}$ and $\mathrm{Mg}$ contents in soil after carrot cultivation (346 times lower than $\mathrm{Ca}$ and 23 times than $\mathrm{Mg}$ on average), mean content of $\mathrm{Na}$ in storage roots was comparable with the mean concentration of $\mathrm{Ca}$ and 2.6 times higher than $\mathrm{Mg}$ content. The results mentioned above may indirectly suggest that in conditions of increased $\mathrm{NO}_{3}^{-}$intake by carrot (as presented in earlier results by Smoleń et al. 2006), we can observe a synergistic effect of this anion on $\mathrm{Na}^{+}$intake. Such a synergistic effect of $\mathrm{NO}_{3}^{-}$on $\mathrm{Na}^{+}$and $\mathrm{K}^{+}$intake was already revealed by Marschner (1995) and Gorham (2007).

The results of our research show that foliar application treatment inconsiderably influences the degree of plant nutrition in micro- and macrocomponents and the levels of heavy metal accumulation and trace elements in carrot storage roots. Foliar nutrition treatment (analysed independently from nitrogen fertilization) resulted only in raised $\mathrm{Bi}$ and $\mathrm{Be}$ as well as $\mathrm{Cu}$ (Smolen and Sady 2007 a) concentration in carrot storage roots. The results of previous research (Smolen and Sady 2006, 2007 b) revealed that the effect of the foliar application treatment on the intake of micronutrients and heavy metals depends equally on the kind and concentration of components applied to plants in this treatment as well as applied soil nitrogen fertilization, physical-chemical properties of soil and climate conditions during cultivation.

As was revealed, under the influence of applied forms of nitrogen fertilizers, significantly varied values of readily soluble forms (in $0.01 \mathrm{M} \mathrm{CaCl}_{2}$ ) of $\mathrm{B}, \mathrm{K}, \mathrm{Mg}$, $\mathrm{Mn}, \mathrm{Na}, \mathrm{Sr}, \mathrm{Be}, \mathrm{Bi}, \mathrm{Li}, \mathrm{Mo}$, and $\mathrm{Ni}$ in soil after carrot cultivation were marked only by an impact on the concentrations of $\mathrm{Mn}$ and $\mathrm{Sr}$ in carrot storage roots. Together 
with elevated contents of $\mathrm{Mn}$ in carrot fertilized with $\left(\mathrm{NH}_{4}\right)_{2} \mathrm{SO}_{4}$, we could observe an increased level of readily soluble forms of this element in the soil. In comparison to other combinations of our experiment, a raise in $\mathrm{Mn}$ forms available for the plants in the soil fertilized in this way could be connected with a considerable decrease in soil reaction (Smolen and Sady 2007 a), which was already presented in the results of Badora's (2002) and Labętowicz and Rutkowska's (2002) research. Other results in the scope of the effect of nitrogen form on Mn concentration in potato leaves were presented by Maier et al. (2002). These authors revealed an apparent increase in Mn concentration in the leaves fertilized with $\mathrm{Ca}\left(\mathrm{NO}_{3}\right)_{2}$ when compared with fertilization with $\mathrm{CO}\left(\mathrm{NH}_{2}\right)_{2}$ and $\left(\mathrm{NH}_{4}\right)_{2} \mathrm{SO}_{4}$.

Kabata-Pendias and Pendias (1999) inform that $\mathrm{Sr}$ is a little-active element in plants and it is accumulated in older leaves, roots and bulbs. Mean content of $\mathrm{Sr}$ in carrot storage roots is marked within 1.5-130 ppm d.w. The same authors reveal that the mechanism of $\mathrm{Sr}$ intake is in a way similar to the $\mathrm{Ca}$ intake mechanism; yet, despite corresponding biochemical properties, $\mathrm{Sr}$ cannot replace $\mathrm{Ca}$ in physiological functions. According to the research cited by these authors, $\mathrm{Ca}$ exerts an antagonistic influence on the concentration of $\mathrm{Sr}$ in roots and stems of beans. Tyler and Olsson (2001), after soil liming with $\mathrm{CaCO}_{3}$, revealed an elevated level of $\mathrm{Sr}$ soil solution as a result of ion exchange of $\mathrm{Sr}$ with $\mathrm{Ca}$ in the soil sorption complex. Similarly, our research shows that fertilization with $\mathrm{Ca}\left(\mathrm{NO}_{3}\right)_{2}$, in comparison with the control and fertilization with other nitrogen fertilizers, resulted in raised contents of a readily soluble form of $\mathrm{Sr}$ in soil as well as its elevated concentrations in carrot. In earlier studies (Smolen and Sady 2008), the heads of 'Langendijker' red cabbage plants fertilized with $\mathrm{Ca}\left(\mathrm{NO}_{3}\right)_{2}$ and $\mathrm{CO}\left(\mathrm{NH}_{2}\right)_{2}$ were characterized by the highest content of $\mathrm{Sr}$ as well as $\mathrm{Al}, \mathrm{Mn}, \mathrm{Zn}, \mathrm{Cd}$ and $\mathrm{Mo}$ in comparison to the control (unfertilized with nitrogen) and plants fertilized with $\left(\mathrm{NH}_{4}\right)_{2} \mathrm{SO}_{4}$ and $\mathrm{NH}_{4} \mathrm{NO}_{3}$. Kalembasa and Wysokiński (2008) revealed increased concentrations of $\mathrm{Sr}$ in corn after fertilization with $\mathrm{CaO}$ and sludge sediments combined with $\mathrm{CaO}$. The results of our research and those presented in other works (Kalembasa and Wysokiński 2008, Smoleń and Sady 2008) show that calcium introduced into soil both in the form of $\mathrm{Ca}\left(\mathrm{NO}_{3}\right)_{2}$ as well as $\mathrm{CaO}$ can influence the increase of Sr intake by plants. Yet, research by Rosen et al. (2006) reveals that $\mathrm{Sr}$ has a synergistic impact on $\mathrm{Ca}$ intake.

The lower the reaction of soil, the less molybdenum available for the plants in the soil (Marschner 1995, Łabętowicz and Rutkowska 2002). However, our research showed that despite a statistically significant drop in soil reaction after the use of $\left(\mathrm{NH}_{4}\right)_{2} \mathrm{SO}_{4}$ (Smoleń et al. 2006), we did not observe a decline in the content of a readily soluble form of Mo in soil after carrot cultivation in comparison to other combinations. It could have been caused by a comparably small decline of soil reaction (by $0.4-0.7 \mathrm{pH}$ ), which occurred at a relatively high soil $\mathrm{pH}$ in 6.076.77. It is worth noting that the revealed decrease of molybdenum content in carrot 
after fertilization with $\left(\mathrm{NH}_{4}\right)_{2} \mathrm{SO}_{4}$ might have resulted from the inhibitive effect of sulphate ions $\left(\mathrm{SO}_{4}{ }^{2-}\right)$ on the plant intake of molybdate ions from the soil $\left(\mathrm{MoO}_{4}{ }^{2-}\right)$ (Marschner 1995). It appears that the plants' decreased molybdenum supply could have been one of the reasons for increased concentrations of nitrate in storage roots of fertilized carrot $\left(\mathrm{NH}_{4}\right)_{2} \mathrm{SO}_{4}$ (Smolen et al. 2006), as molybdenum plays the role of the cofactor of nitrate reductase - an enzyme responsible for nitrate reduction in plants (Campbell 1999). It shall be noted, however, that both in leaves (Wojciechowska et al. 2006) as well as in storage roots of carrot (Smoleń et al. 2006), no apparent effect of $\left(\mathrm{NH}_{4}\right)_{2} \mathrm{SO}_{4}$ fertilization on the level of nitrate reductase activity was revealed.

\section{CONCLUSIONS}

1. Taking into consideration all elements ( $\mathrm{Al}, \mathrm{As}, \mathrm{B}, \mathrm{Ba}, \mathrm{Be}, \mathrm{Bi}, \mathrm{Ca}, \mathrm{Co}, \mathrm{Cr}, \mathrm{Fe}$, $\mathrm{Ga}$, In, K, Li, Mg, Mn, Mo, Na, Ni, Pb, Sb, Se, Sr, Ti and V), there was a significant effect of the interaction between foliar application and nitrogen fertilization only in the case of $\mathrm{Na}$ content in carrot storage roots. In comparison with the plants unfertilized foliarly, a considerable increase in the content of $\mathrm{Na}$ in storage roots after foliar application was observed in plants fertilized with $\mathrm{Ca}\left(\mathrm{NO}_{3}\right)_{2}$.

2. In comparison with the control plants unfertilized with nitrogen, all applied fertilizers caused an increase in the content of $\mathrm{Mg}$ and $\mathrm{Se}$ in carrot.

3. Fertilization with $\left(\mathrm{NH}_{4}\right)_{2} \mathrm{SO}_{4}$ resulted in decreased concentrations of $\mathrm{Ba}$ and Mo and increased $\mathrm{Mn}$, while fertilization with $\mathrm{Ca}\left(\mathrm{NO}_{3}\right)_{2}$ had a significant effect on elevated concentrations of $\mathrm{Sr}$ and $\mathrm{Be}$ in carrot.

4. Foliar application considerably raised the contents of $\mathrm{Be}$ and $\mathrm{Bi}$, but had no influence of the concentrations of other elements: $\mathrm{Al}, \mathrm{As}, \mathrm{B}, \mathrm{Ba}, \mathrm{Ca}, \mathrm{Co}, \mathrm{Cr}$, $\mathrm{Fe}, \mathrm{Ga}, \mathrm{In}, \mathrm{K}, \mathrm{Li}, \mathrm{Mg}, \mathrm{Mn}, \mathrm{Mo}, \mathrm{Na}, \mathrm{Ni}, \mathrm{Pb}, \mathrm{Sb}, \mathrm{Se}, \mathrm{Sr}$, Ti and V.

\section{REFERENCES}

ADAMEC L., 2002. Leaf absorption of mineral nutrients in carnivorous plants stimulates root nutrient uptake. New Phytol. 155(1): 89-100.

BADORA A., 2002. Influence of pH on the mobility of elements in soil. Zesz. Probl. Post. Nauk Roln. 482: 21-36.

CAMPBELL W.H., 1999. Nitrate reductase structure, function and regulation: Bridging the gap between biochemistry and physiology. Ann. Rev. Plant Physiol. Plant. Mol. Biol. 50: 277-303. 
CHWIL S., SzEWCZUK C., 2003. Wpływ dolistnego dokarmiania buraka cukrowego na plon i niektóre cechy jakościowe. Acta Agroph. 85: 117-124.

CzeKAlA J., JAKUBUS M., 2006. Influence of long-term plant cultivation and nitrogen fertilization on the content of soluble forms of trace elements in a lessive soil. Polish J. Environ. Stud. 15(2a), Part I: 36-41.

DiATTA J.B., GRZEBISZ W., 2006. Influence of mineral nitrogen forms on heavy metals mobility in two soils. Polish J. Environ. Stud. 15(2a), Part I: 56-62.

GĘBSKI M., 1998. Czynniki glebowe oraz nawozowe wpływające na przyswajanie metali ciężkich przez rośliny. Post. Nauk Roln. 5: 3-16.

GĘBSKI M., MERCIK S., 1997. Effectiveness of fertiliser form in accumulation of zinc, cadmium and lead in lettuce (Lactuca sativa L.) and red beet (Beta vulgaris var. cicla L.). Ecological aspects of nutrition and alternatives for herbicides in horticulture. International Sem. Warsaw, 10-15 June: 23-25.

GORHAM J., 2007. Sodium. In: Handbook of plant nutrition. A.V. Barker and D.J. Pilbeam (eds). Taylor \& Francis Group, LLC, New York: 569-583.

HASSAN M.J., WANG F., Ali S., ZHANG G., 2005. Toxic effect of cadmium on rice as affected by nitrogen fertilizer form. Plant Soil 277: 359-365.

HASSAN M.J., ZHANG G., ZHU Z., 2008. Influence of cadmium toxicity on plant growth and nitrogen uptake in rice as affected by nitrogen form. J. Plant Nutr. 31: 251-262.

HoubA V.J.G., Novozamsky I., Temminghoff E., 1997. Soil analysis procedures. Extraction with $0.01 \mathrm{M} \mathrm{CaCL}_{2}$ (Soil and Plant Analysis, Part 5A). Wageningen Agricultural University, The Netherlands, 93 pp.

JURKOWSKA H., RoGÓż A., 1981. Wpływ formy i dawki azotu na zawartość makro i mikroelementów w roślinach. Part. II: Mikroelementy. Acta Agr. Silv., Ser. Agr. 20: 121-131.

JURKOWSKA H., WiŚNIOWSKA-KIELIAN B., WOJCIECHOWICZ T., 1981. Wpływ formy i dawki azotu na zawartość makro i mikroelementów w roślinach. Part. I: Makroelementy. Acta Agr. Silv., Ser. Agr. 20: 107-120.

Kabata-Pendias A., Pendias H., 1999. Biogeochemia pierwiastków śladowych. Wyd. II. PWN, Warszawa, 398 pp.

KAlEMBASA S., WYSOKIŃSKi A., 2008. The content of Ti, Sr, Co and Li in plant fertilized fresh and composted waste sludge mixed with $\mathrm{CaO}$, ash, wood shavings and straw. Trace Elements in the Environment - Ecological and Methodical Problems. Trace Elements in Food Chain. In: IX Symposium Series Trace Elements in the Environment. Koszalin-Mielno, 11-14 May, Poland. Book of Abstracts: 162-163. 
Komornicki T., Oleksynowa K., ToKaj J., JakUBieC J., 1991. Przewodnik do ćwiczeń z gleboznawstwa i geologii. Part. II. Metody laboratoryjne analizy gleb. Skrypt AR w Krakowie, 140 pp.

ŁABĘTOWICZ J., RUTKOWSKA B., 2002. Effect of soil reaction on micronutrient concentration in soil solution of arable soils in Poland. Zesz. Probl. Post. Nauk Roln. 482: 337-342.

Maier N.A., LAUGHLin M.J., HeAP M., ButT M., SMART M.K., 2002. Effect of nitrogen source and calcitic lime on soil $\mathrm{pH}$ and potato yield, leaf chemical composition, and tuber cadmium concentrations. J. Plant Nutr. 25(3): 523-544.

MARSCHNER H., 1995. Mineral Nutrition of Higher Plants. Second ed. Academic Press, London, England, $889 \mathrm{pp}$.

NOWOSIELSKI O., 1988. Zasady opracowywania zaleceń nawozowych w ogrodnictwie. PWRiL, Warszawa, 312 pp.

PASŁAWSKI P., MIGASZEWSKI Z.M., 2006. The quality of element determinations in plant materials by instrumental methods. Polish J. Environ. Stud. 15(2a), Part I: 154-164.

RODRÍGUEZ-ORTÍZ J.C., VALDEZ-CEPEDA R.D., LARA-MIRELES J.L., RODRÍGUEZFuentes H., VÁZQuez-Alvarado R.E., Magallanes-Quintanar R., GARCÍA-HERNÁNDEZ. J.L., 2006. Soil nitrogen fertilization effects on phytoextraction of cadmium and lead by tobacco (Nicotiana tabacum L.). Biorem. J. 10(3): 105-114.

Rosen C.J., Bierman P., Telias A., HoOver E., 2006. Foliar- and fruit-applied strontium as a tracer for calcium transport in apple trees. HortScience 41: 220-224.

RoŻEK S., 2000. Czynniki wpływające na akumulację azotanów w plonie warzyw. Zesz. Nauk. AR Kraków 364(71): 19-31.

SADY W., SMOLEŃ S., 2004. Wpływ czynników glebowo-nawozowych na akumulację metali ciężkich w roślinach. Roczn. AR w Poznaniu XXXCLVI, Ogrod. 37: 269-277.

SMOLEŃ S., 2008. The effect of foliar nutrition with nitrogen, molybdenum, sucrose and benzyladenine on the concentrations of $\mathrm{Cd}, \mathrm{Fe}, \mathrm{Mn}, \mathrm{Pb}$ and $\mathrm{Zn}$ in radish. Ann. Univ. M. Curie-Skłodowska, Sect.E. 63(4): 34-41.

SMOLEŃ S., SADY W., 2006. The content of $\mathrm{Cd}, \mathrm{Cu}$ and $\mathrm{Zn}$ in carrot storage roots as related to differentiated nitrogen fertilization and foliar nutrition. Pol. J. Environ. Stud. 15(2a), Part II: 503-509.

SMOLEŃ S., SADY W., 2007 a. The effect of nitrogen fertilizer form and foliar application on $\mathrm{Cd}, \mathrm{Cu}$ and $\mathrm{Zn}$ concentrations in carrot. Folia Hort. 19/1: 87-96.

SMOLEŃ S., SADY W., 2007 b. The effect of nitric fertilizer with nitrification inhibitor and foliar-nutrition on the content of dry weight, $\mathrm{Cd}, \mathrm{Cu}$, and $\mathrm{Zn}$ in carrots. Ochr. Środ. i Zas. Nat. 32: 81-86. 
SMOLEŃ S., SADY W., 2008. The effect of nitrogen fertilizer form on the content of sixteen elements in red cabbage. Acta Scien. Pol. Hort. Cult. 7(1): 35-44.

SMOLEŃ S., WOJCIECHOWSKA R., SADY W., SZURA A., 2006. The effect of fertilization with different forms of nitrogen and foliar nutrition on yield and nitrogen metabolism in carrot roots (Daucus carota L.). Acta Agroph. 7(3): 721-732.

TYLER G., OlsSON T., 2001. Concentrations of 60 elements in the soil solution as related to the soil acidity. Europ. J. Soil Sci. 52: 151-165.

Wojciechowska R., SmoleŃ S., SAdy W., KoŁTON A., 2006. Nitrate reduction in carrot leaves in relation to foliar nutrition and different forms of nitrogen fertilizer. Acta Agroph. 7(3): 763-774.

\section{WPEYW FORMY AZOTU I DOKARMIANIA DOLISTNEGO NA ZAWARTOŚĆ DWUDZIESTU PIĘCIU PIERWIASTKÓW W MARCHWI}

Streszczenie: Spośród uwzględnionych w badaniach pierwiastków (Al, As, B, Ba, $\mathrm{Be}, \mathrm{Bi}, \mathrm{Ca}, \mathrm{Co}, \mathrm{Cr}, \mathrm{Fe}, \mathrm{Ga}$, In, K, Li, Mg, Mn, Mo, Na, Ni, Pb, Sb, Se, Sr, Ti oraz V) stwierdzono istotny wpływ interakcji dokarmiania dolistnego $\mathrm{z}$ nawożeniem azotem jedynie $\mathrm{w}$ odniesieniu do zawartości $\mathrm{Na} \mathrm{w}$ marchwi 'Kazan $\mathrm{F}_{1}$ '. W przypadku roślin nawożonych $\mathrm{Ca}\left(\mathrm{NO}_{3}\right)_{2}$ dokarmianie dolistne powodowało istotne zwiększenie zawartości Na w korzeniach spichrzowych. W porównaniu do kontroli zastosowane nawozy azotowe (wyniki analizowane niezależnie od czynnika dokarmiania dolistnego) powodowały zwiększenie zawartości Mg i Se w marchwi. Nawożenie $\left(\mathrm{NH}_{4}\right)_{2} \mathrm{SO}_{4}$ powodowało istotne zmniejszenie zawartości Ba i Mo oraz zwiększenie zawartości Mn, a nawożenie $\mathrm{Ca}\left(\mathrm{NO}_{3}\right)_{2}$ powodowało istotne zwiększenie zawartości $\mathrm{Sr}$ i Be w marchwi. Dokarmianie dolistne (analizowane niezależnie od nawożenia azotem) w istotny sposób zwiększyło zawartość $\mathrm{Bi}$ i Be w marchwi, nie miało natomiast wpływu na zawartość pozostałych pierwiastków w korzeniach spichrzowych. 